\title{
Wax Apple (Syzygium samarangense (Blume) Merr. \& L.M. Perry): A Comprehensive Review in Phytochemical and Physiological Perspectives
}

\author{
Arnia Sari Mukaromah' \\ 1Departement of Biology, Faculty of Science and Technology, \\ Universitas Islam Negeri Walisongo Semarang \\ E-mail:arnia_sm@walisongo.ac.id
}

\begin{abstract}
Wax apple (Syzygium samarangense (Blume) Merr. \& L.M. Perry) is a tropical non-climacteric fruit and belongs to Myrtaceae. It has high diversity in cultivars, metabolite content, and its biological activities. In this comprehensive review, research findings had revealed that various metabolites found in the wax apple have biological activities. The said biological activities such as: antioxidant, immunomodulatory, antibacterial, anticancer, anti-glycation, anti-inflammation, anti-hypertriglyceridemic, anti-hyperglycemic, relaxant, and spasmolytic activities. Other potential use for the metabolites also includes the treatments for neurodegenerative abnormality, analgesic, and central nervous system (CNS) depression agent. Furthermore, wax apple physiological and phytochemical characteristics can be enhanced by girdling technique, hydrogen peroxide treatment, plant growth regulators treatment, and fruit bagging treatment. Meanwhile, postharvest technology of wax apple fruit utilizes nitric oxide treatment, oxalic acid treatment, cold treatment, and Aloe vera gel coating. Wax apple has also been evolved as an ointment, anti-acne cream, and nata de guava. However, environmental stress becomes a challenge in the wax apple plantation. Therefore, the development of molecular biology, chemistry, and postharvest technology will solve those challenges. This review concludes that wax apple ( $S$. samarangense) is a tropical fruit that promises to support the nutritional values and human health.
\end{abstract}

Keywords: Wax apple, Metabolite, Biological activities, Fruit quality enhancement

\begin{abstract}
Abstrak
Wax apple (Syzygium samarangense (Blume) Merr. \& L.M. Perry) adalah buah tropis non klimakterik dan termasuk dalam keluarga Myrtaceae. Buah ini memiliki keanekaragaman kultivar yang tinggi, kandungan metabolit dan aktivitas biologisnya. Dalam tinjauan komprehensif ini, penelitian menemukan berbagai metabolit dalam wax apple memiliki aktivitas biologis seperti antioksidan, imunomodulator, antibakteri, antikanker, anti-glikasi dan anti-inflamasi, anti-hipertrigliseridemia, anti-hiperglikemik, relaksasi, spasmolitik, pengobatan kelainan neurodegeneratif, dan agen depresi analgesik sistem saraf pusat (SSP). Selain itu, karakteristik fisiologis dan fitokimia wax apple dapat ditingkatkan melalui girdling technique, perlakuan hidrogen peroksida, penggunaan zat pengatur pertumbuhan tanaman, dan perlakuan pembungkusan buah. Sementara itu, teknologi pasca panen buah wax apple menggunakan perlakuan nitrat oksida, perlakuan asam oksalat, perlakuan suhu dingin, dan pelapis gel lidah buaya. Wax apple juga telah dikembangkan sebagai salep, krim anti-jerawat, dan nata de jambu. Namun, cekaman lingkungan akan menjadi tantangan di perkebunan wax apple. Oleh karena itu, perkembangan di bidang biologi molekuler, kimia dan teknologi pasca panen akan menyelesaikan tantangan tersebut. Kajian ini menyimpulkan bahwa wax apple (S. samarangense adalah buah tropis yang menjanjikan untuk mendukung nilai-nilai gizi dan kesehatan manusia.
\end{abstract}

Kata kunci: Wax apple, Metabolit, Aktivitas biologis, Peningkatan kualitas buah

\section{Introduction}

Syzygium samarangense (Blume) Merr. \& L.M. Perry, a tropical non-climacteric fruit that belongs to Myrtaceae, can be found in South Asia, Southeast Asia, Taiwan, and other tropical countries. S. samarangense has various local names such as wax apple; java apple; water apple; djamboe semarang, jambu semarang, samarang rose apple (Indonesia); makopa (Philipppines); chomp u kao or chomp u kio, etc. (Morton, 1987; Shü, Shiesh, \& Lin, 2011; Widodo, 2015). It is commonly cultivated in the low land, and it's flowering and fruit production influenced by 
light. Wax apple fruit has high diversity in cultivars and recommended as an export product with high economic values. Wax apple fruit can be generally utilized as fresh fruit, juice, jelly, and medicine. However, wax apple leaves are commonly used as medicine and food cover. Indonesian wax apple fruit has four subspecies and 73 cultivars. Meanwhile, other countries have other various popular wax apple cultivars. Wax apple fruit cultivars have various color, taste, fruit texture, and shape (Widodo, 2015). The various physiological, phytochemical, and biological activities of wax apple cultivars have been known. The aims of this review are to investigate the diversity of wax apple cultivars, identify the phytochemical and biological activities of wax apple cultivars, explore the technology for phytochemical and physiological characteristics enhancement, show the environmental challenges and its cultivars adaptation, postharvest technology, explore the wax apple product development and predict the future perspectives.

\section{Syzygium samarangense (Blume) Merr. \& L.M. Perry Morphology}

Wax apple plants include small or mediumsized trees that have a height of 4-15 $\mathrm{m}$ and 5-40 $\mathrm{cm}$ in diameter. It shows a straight or irregular winding stem with many branches. The stem is brownish gray with a rough and peeling bark or not. The cylindrical or slightly flaky branch is located under the nodes, reddish-brown in color, and 2-4 $\mathrm{mm}$ in diameter. In general, leaf strands are stretched, extending to the lancet-the length and width of the leaves in the range of $6-30 \mathrm{~cm}$ and 4-15 cm. Wax apple flower is consisting of $3,9,15$ or more flowers, which can be found at the tip, armpits of leaves, twigs, and old branches. The length of the flower stalk is around 3-5 mm with a width of $8-10 \mathrm{~mm}$, and the flower calyx is semicircular, yellowish-green, or white. The corolla is rounded, white with a length of 8-12 mm. Stamens number around 200-500 with a length of 3-4 cm. Meanwhile, the pistils are one $\mathrm{mm}$ in diameter with a length of $4 \mathrm{~cm}$. The fruit is bell-shaped, has a pseudostipe or is not equipped with a pseudostipe as seen in a rounded, obovateshaped wax apple. Furthermore, Indonesian wax apple grown in Papua has a vertical and concave flat shape on the base. Moreover, the presence of Syzygium aqueum has usually confused with $S$. samarangense in the field (Widodo, 2015). Therefore, Widodo (2015) had been developed determination keys to differ $S$. samarangense cultivars and Syzygium aqueum.

\section{Syzygium samarangense (Blume) Merr. \& L.M. Perry Cultivars}

In Indonesia, Syzygium samarangense can be found at Sumatra, Java and Papua. However, $S$. samarangense 'Citra' and $S$. samarangense 'Delima' have been the most cultivated cultivars especially in the Central Java province (Widodo, 2015). Furthermore, the wax apple tree has been cultivated with minor economic status in Malaysia (Milow, Malek, Edo, \& Ong, 2014). There are popular wax apple fruit cultivars such as 'Masam Manis Pink', 'Giant Green', and 'Jambu Madu Red'. These cultivars reveal differences in the physiological responses such as stomatal conductance, net photosynthesis, chlorophyll content, carotenoid content, and leaf area. According to (Idris, Ismail, Mat, \& Khandaker, 2018; Mohammad Moneruzzaman Khandaker, Alebidi, Hossain, Mat, \& Boyce, 2015), 'Jambu Merah Red' and 'Masam Manis Pink' cultivars show the highest physiological characters than other cultivars. Therefore, wax apple fruit 'Jambu Merah Red' and 'Masam Manis Pink' recommended cultivating in Malaysia and South Asian countries (Idris et al., 2018; Mohammad Moneruzzaman Khandaker et al., 2015; Moneruzzaman, Al-Saif, et al., 2011). The number of wax apple cultivars can be shown in Table 1 . and Table 2.

Table 1. Indonesian Wax Apple Syzygium samarangense (Blume) Merr. \& L.M. Perry Subspecies and Cultivars (Widodo, 2015)

\begin{tabular}{|c|c|c|c|}
\hline No. & Subspecies Type & $\begin{array}{c}\text { Specific } \\
\text { Characteristics }\end{array}$ & Cultivar type \\
\hline 1. & $\begin{array}{l}\text { Syzygium samarangense } \\
\text { subsp. album Widodo } \\
\text { subsp. nov. }\end{array}$ & $\begin{array}{l}\text { White fruit until } \\
\text { ripening } \\
\text { condition }\end{array}$ & $\begin{array}{ll}- & \text { Syzygium samarangense 'Kaget Putih' } \\
- & \text { Syzygium samarangense 'Mutiara' } \\
- & \text { Syzygium samarangense 'Madura Putih' } \\
\text { - } & \text { Syzygium samarangense 'Tamansari Putih' } \\
& \text { Widodo cult. nov } \\
\text { - } & \text { Syzygium samarangense 'Bancarkembar Putih' } \\
- & \text { Syzygium samarangense 'Berlian Putih' cult. } \\
& \text { nov. } \\
- & \text { Syzygium samarangense 'Fateta IPB' } \\
- & \text { Syzygium samarangense 'Lilin Putih' }\end{array}$ \\
\hline
\end{tabular}




\begin{tabular}{|c|c|c|c|}
\hline No. & Subspecies Type & $\begin{array}{c}\text { Specific } \\
\text { Characteristics }\end{array}$ & Cultivar type \\
\hline & & & $\begin{array}{ll}\text { - } & \text { Syzygium samarangense 'Sokaraja Putih' } \\
& \text { Widodo cult.nov } \\
\text { - } & \text { Syzygium samarangense 'Karangsalam Putih' } \\
\text { - } & \text { Syzygium samarangense 'Dot Putih' cult. nov. } \\
\text { - } & \text { Syzygium samarangense 'Camplong Putih' } \\
\text { - } & \text { Syzygium samarangense 'Klampok Putih' } \\
& \text { Widodo cult. nov } \\
\text { - } & \text { Syzygium samarangense 'Asli Sumatra' }\end{array}$ \\
\hline 2. & $\begin{array}{l}\text { Syzygium samarangense } \\
\text { subsp. viride Widodo } \\
\text { subsp. nov. }\end{array}$ & $\begin{array}{l}\text { Green fruit, } \\
\text { sometimes } \\
\text { appear other } \\
\text { colors such as } \\
\text { white, } \\
\text { yellowish or } \\
\text { pink in the fruit } \\
\text { tip. } \\
\text { Green color } \\
\text { fruit appears } \\
\text { until the } \\
\text { ripening stage. }\end{array}$ & 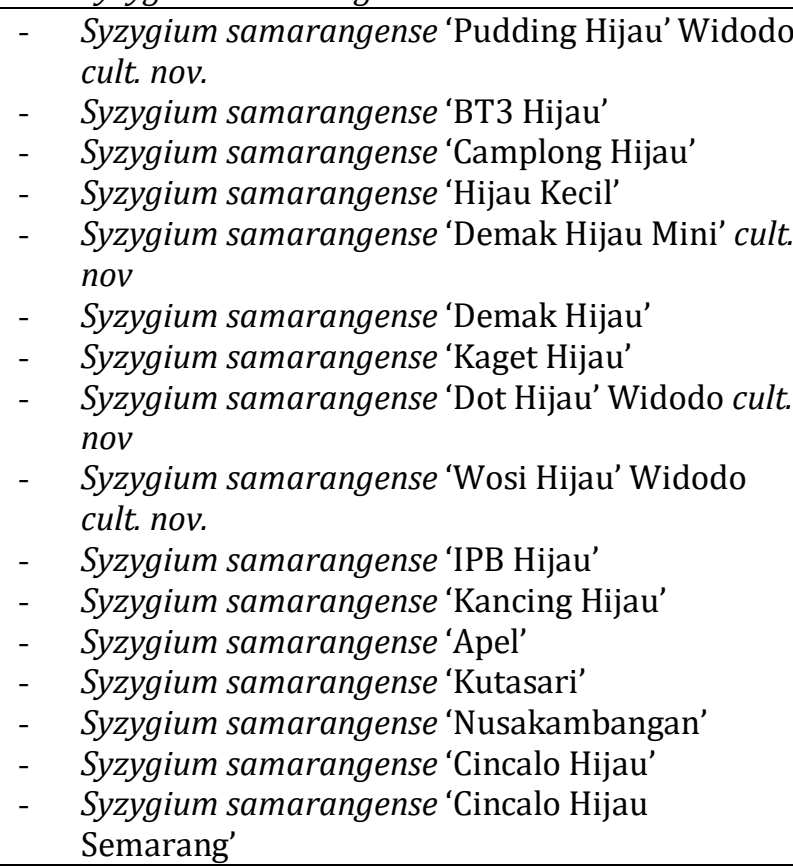 \\
\hline 3. & $\begin{array}{l}\text { Syzygium samarangense } \\
\text { subsp. roseum Widiawati } \\
\text { subsp. nov. }\end{array}$ & $\begin{array}{l}\text { Pink color- } \\
\text { reddish fruit }\end{array}$ & $\begin{array}{ll}- & \text { Syzygium samarangense 'Madu Panjang' } \\
\text { - } & \text { Syzygium samarangense 'Cincalo Merah } \\
& \text { Mekarsari' } \\
- & \text { Syzygium samarangense 'Yogya Pink' } \\
- & \text { Syzygium samarangense 'Kebocoran Pink' } \\
- & \text { Syzygium samarangense 'Cincalo Pink' } \\
- & \text { Syzygium samarangense 'Kaget Oranye' } \\
- & \text { Syzygium samarangense 'Klampok Sukaluyu' } \\
- & \text { Syzygium samarangense 'Klampok Karangsalam' } \\
- & \text { Syzygium samarangense 'Padang Pink' } \\
- & \text { Syzygium samarangense 'Lilin Pink' } \\
- & \text { Syzygium samarangense 'Tangkweh' } \\
- & \text { Syzygium samarangense 'Bell Apple' } \\
- & \text { Syzygium samarangense 'Reremi Yapis' Widodo } \\
& \text { cult. nov. } \\
- & \text { Syzygium samarangense 'Cincalo Merah' } \\
- & \text { Syzygium samarangense 'Banjarsari Kulon' } \\
- & \text { Syzygium samarangense 'Camplong Kuning' } \\
- & \text { Syzygium samarangense 'Kancing Kuning' } \\
- & \text { Syzygium samarangense 'Lilin Merah' } \\
- & \text { Syzygium samarangense 'Kalibamban' } \\
- & \text { Syzygium samarangense 'Manokwari Pink' } \\
- & \text { Syzygium samarangense 'Lilin Pink' } \\
- & \text { Syzygium samarangense 'Mutiara Merah' } \\
\end{array}$ \\
\hline
\end{tabular}




\begin{tabular}{|c|c|c|c|}
\hline No. & Subspecies Type & $\begin{array}{l}\text { Specific } \\
\text { Characteristics }\end{array}$ & Cultivar type \\
\hline 4. & $\begin{array}{l}\text { Syzygium samarangense } \\
\text { subsp. rubrum Widodo } \\
\text { subsp. nov. }\end{array}$ & $\begin{array}{l}\text { Red - dark red } \\
\text { fruit }\end{array}$ & $\begin{array}{ll}\text { - } & \text { Syzygium samarangense 'Kaget Merah' } \\
\text { - } & \text { Syzygium samarangense 'Irung Petruk' } \\
\text { - } & \text { Syzygium samarangense 'Silado' } \\
\text { - } & \text { Syzygium samarangense 'Pink Rose Apple' } \\
\text { - } & \text { Syzygium samarangense 'Purwokerto' } \\
- & \text { Syzygium samarangense 'King Rose Apple' } \\
\text { - } & \text { Syzygium samarangense 'Arcawinangun' } \\
- & \text { Syzygium samarangense 'Kecil Sumpyuh' } \\
- & \text { Syzygium samarangense 'Baturraden Maroon' } \\
- & \text { Syzygium samarangense 'Cincalo Maroon' } \\
- & \text { Syzygium samarangense 'Cokelat' } \\
- & \text { Syzygium samarangense 'Lilin Maroon' } \\
- & \text { Syzygium samarangense 'Citra' } \\
- & \text { Syzygium samarangense 'Merah Delima' } \\
- & \text { Syzygium samarangense 'Dot Merah' cult. nov. } \\
- & \text { Syzygium samarangense 'Unsoed' } \\
- & \text { Syzygium samarangense 'Cindaga' } \\
- & \text { Syzygium samarangense 'Sanggeng' } \\
- & \text { Syzygium samarangense 'Rowokele Manis' } \\
- & \text { Syzygium samarangense 'Demak Merah Mini' } \\
- & \text { Syzygium samarangense 'Samaraqua' }\end{array}$ \\
\hline
\end{tabular}

Table 2. Other popular wax apples (Syzygium samarangense (Blume) Merr. \& L.M. Perry) cultivars

\begin{tabular}{|c|c|c|c|}
\hline No. & Region & Cultivar type & References \\
\hline 1. & Malaysia & $\begin{array}{l}\text { - } \quad \text { Syzygium samarangense 'Masam } \\
\text { Manis Pink' } \\
\text { - Syzygium samarangense 'Jambu } \\
\text { Madu Red' } \\
\text { - Syzygium samarangense 'Giant } \\
\text { Green' }\end{array}$ & $\begin{array}{l}\text { (Idris et al., 2018) } \\
\text { (Mohammad Moneruzzaman } \\
\text { Khandaker et al., 2015) } \\
\text { (Moneruzzaman, Al-Saif, et al., } \\
\text { 2011) }\end{array}$ \\
\hline 2. & Thailand & $\begin{array}{l}\text { - } \quad \text { Syzygium samarangense } \\
\text { 'Thongsamsee' } \\
\text { - Syzygium samarangense } \\
\text { 'Taaptimjaan' } \\
\text { - Syzygium samarangense } \\
\text { 'Thabthimchan' }\end{array}$ & $\begin{array}{l}\text { (Muchjajib, Muchjajib, \& Jumee, } \\
\text { 2016) } \\
\text { (Mothina \& Yapwattanaphun, } \\
\text { 2017) } \\
\text { (Supapvanich, Mitrsang, } \\
\text { Srinorkham, Boonyaritthongchai, } \\
\text { \& Wongs-Aree, 2016) }\end{array}$ \\
\hline 3. & Taiwan & $\begin{array}{l}\text { - Syzygium samarangense 'Taiwan } \\
\text { Pink' }\end{array}$ & $\begin{array}{l}\text { (Reynertson, Yang, Jiang, Basile, \& } \\
\text { Kennelly, 2008) }\end{array}$ \\
\hline
\end{tabular}




\section{Molecular Systematics Analysis of Wax Apple Cultivars}

In Malaysia, wax apple cultivars ('Masam Manis Pink'; 'Jambu Madu Red'; Giant Green) differ in the morphological and physiological characteristics. It may be influenced by genetic diversity (Mohammad Moneruzzaman Khandaker, Alebidi, \& Al-saif, 2012). The genome size of diploid $S$. samarangense is $0,56 \mathrm{pg}(2 \mathrm{C}$ DNA) equivalent with 548,33 Mbp length (Matra et al., 2019). Meanwhile, chloroplast genome sequences can be developed as some molecular markers for phylogenetic and population genetic analysis of wax apple. The chloroplast genome of S. samaragense MH371141 is 159,109 bp and consists of 113 genes. The chloroplast genome consists of a single large copy $(88,533 \mathrm{bp})$, a small single copy $(18,882 \mathrm{bp})$, and an inverted repeat region (25,847 bp) (Liu, Ni, Zheng, Shi, \& Niu, 2018). Random Amplified Polymorphic DNA (RAPD), and Inter Simple Sequence Repeat (ISSR) have been utilized in Syzygium phylogeny analysis. However, its techniques are not able to reveal phylogenetic relation between Syzygium species. Therefore, plant DNA barcoding is better used to observe phylogenetic analysis (Cheong \& Ranghoo-Sanmukhiya, 2013). Furthermore, the twenty new primers can be analyzed for the microsatellite loci of wax apple. It is utilized to genetic diversity determination, cultivar identification, lineage analysis, and linkage mapping in wax apple species (Lai et al., 2015). Besides, Simple Sequence Repeats (SRR) specified for Syzygium species contribute to getting comprehensive information about the relationship between species, taxonomy, structure and genetic diversity, genetic mapping, breeding, and conservation program(Nogueira, Ferreira, \& da Silva Ferreira, 2016). Comprehensive molecular systematic analysis of wax apple cultivars has not been reported yet. Therefore, the development of a molecular marker for DNA barcoding analysis and DNA fingerprinting is very recommended to identify, explore, and determine was apple cultivars diversity. 


\section{Metabolite Content and Biological Activities}

Wax apple tree has diverse metabolite content, which spreads in whole plants with interest biological activities. The details of metabolite content and biological activities have been shown in Table 3.

Table 3. Metabolite Content and Biological Activities of Wax Apple (Syzygium samarangense (Blume) Merr. \& L.M. Perry)

\begin{tabular}{|c|c|c|c|c|}
\hline $\begin{array}{c}\text { Wax apple } \\
\text { part }\end{array}$ & $\begin{array}{c}\text { The type of } \\
\text { extract/fraction }\end{array}$ & Metabolite content & Biological Activities & References \\
\hline Leaves & Methanol & 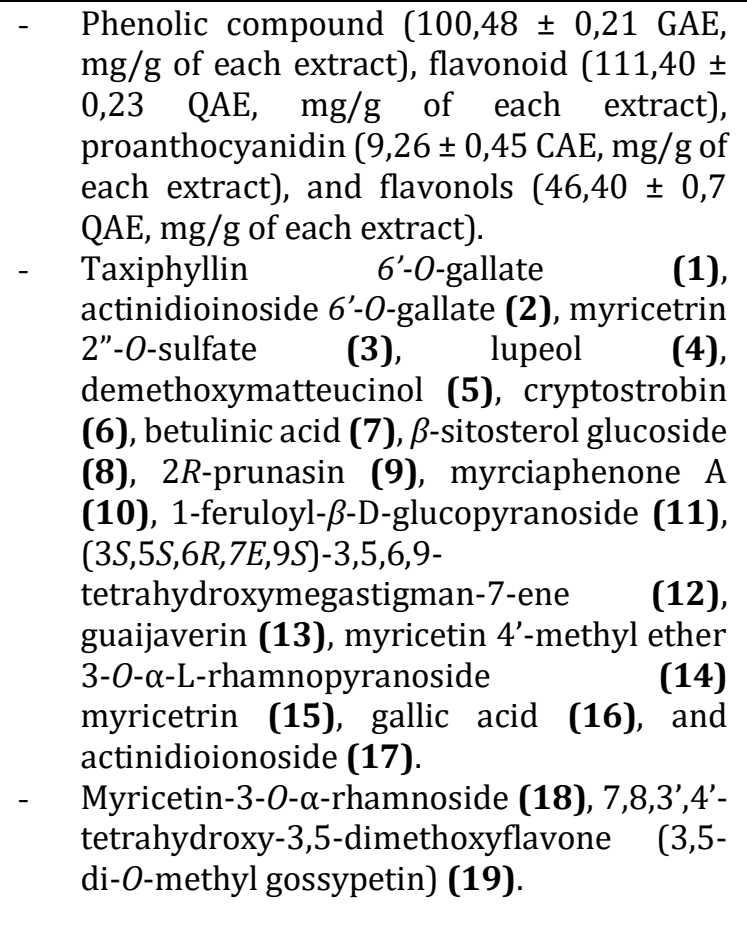 & $\begin{array}{l}\text { - The methanol extract of S. samarangense leaves } \\
\text { (MSSL) and bark (MSSB) function as analgesic, } \\
\text { anti-inflammatory, central nervous system (CNS) } \\
\text { depression agent, anti-diarrheal activity } \\
\text { (Majumder, Nur-E-Hasnat, Ashraf-Uz-Zaman, \& } \\
\text { Alam, 2014), and anti-hyperglycemic activity } \\
\text { (Shahreen et al., 2012). } \\
\text { The MSSL reveals higher antioxidant activity } \\
\text { than a various solvent-soluble fraction of S. } \\
\text { samarangense leaves (Majumder, Alam, } \\
\text { Chowdhury, Bajpai, \& Shukla, 2017). } \\
\text { Compounds 1, 3, and 13-16 have significant } \\
\text { antioxidant activity (Mamdouh Nabil Samy, } \\
\text { Sugimoto, Matsunami, Otsuka, \& Kamel, 2014). } \\
\text { Potential candidate for antioxidant and liver- } \\
\text { protecting medicine (Sobeh et al., 2018). } \\
\text { Compound 18, and 19 have an antioxidant and } \\
\text { anti-inflammatory effect. } \\
\text { 3,5-di-O-methyl gossypetin (19) shows the } \\
\text { antioxidant activity by nuclear transcription } \\
\text { factor-2 (Nrf-2) pathway and stimulating } \\
\text { antioxidant protein such as HO-1 and Mn-SOD-3 } \\
\text { (Sobeh et al., 2019). }\end{array}$ & $\begin{array}{l}\text { (Majumder et al., } \\
\text { 2014); } \\
\text { (Shahreen et al., } \\
\text { 2012); } \\
\text { (Majumder et al., } \\
\text { 2017); } \\
\text { (Mamdouh Nabil } \\
\text { Samy et al., 2014) } \\
\text { (Sobeh et al., } \\
\text { 2018) }\end{array}$ \\
\hline
\end{tabular}




\section{Table 3. Continued

Wax apple \\ part}

The type of extract/fraction

Leaves Ethanol
Metabolite content

\section{Biological Activities}

- Flavonol glycosides such as mearnsitrin and 2'-C-methyl-5'-Ogalloylmyricetin-3-O- $\alpha$-Lrhamnopyranoside (2).

- Nine acylphloroglucinol derivates (311).

- $\quad$ Castalagin $(0.12 \%) \mathbf{( 1 2 )}$ and vescalagin $(0.29 \%)$ (13).

\begin{tabular}{lll}
\hline Leaves & Ethyl acetate & Phenolic compound $(148,57 \pm 0,22 \mathrm{GAE}$, \\
& fraction (ESSL) & $\mathrm{mg} / \mathrm{g}$ of each extract), flavonoid $(207,40$ \\
& $\pm 0,12 \mathrm{QAE}, \mathrm{mg} / \mathrm{g}$ of each extract), \\
& proanthocyanidin $(16,87 \pm 0,58 \mathrm{CAE}$, \\
& $\mathrm{mg} / \mathrm{g}$ of each extract), and flavonols \\
& $(57,80 \pm 0,05 \mathrm{QAE}, \mathrm{mg} / \mathrm{g}$ of each extract). \\
& Acetone & $\begin{array}{l}\text { Acetone extract of wax apple leaves } \\
\text { contains sixteen various flavonoid } \\
\end{array}$ \\
& compounds.
\end{tabular}

S. samarangense leaves reveal antibacterial activity (Choironi toward Bacillus cereus and Salmonella enterica with Fareza, 2018) minimum inhibition concentration at $78 \mu \mathrm{g} / \mathrm{mL}$ (Nair, Krishnan, (Choironi \& Fareza, 2018).

Ravikrishna, \& Nine acylphloroglucinol derivates have cytotoxic Madhusudanan, activity against HepG2 and MDA-MB-231 tumor cell 1999); lines (Yang et al., 2018). suggested as (Kamada et al., powerful poly(ADP-ribose) polymerase 1 (PARP1) 2018) inhibitors and DNA topoisomerase II. Therefore, its compounds promise as a cancer chemotherapy agent (Kamada et al., 2018) Ethyl acetate fraction (ESSL) show higher (Majumder et al., antioxidant activity than other fractions and may use 2017) in the free radical interceded disease treatment.

There are four flavonoid compounds having (Kuo, Yang, \& Lin, immunomodulatory activity such as (-)-strobopinin, 2004) myricetin 3-O-(2"-O-galloyl)- $\alpha$-rhamnopyranoside, ()-epigallocatechin 3-O-gallate, and myricetin 3-O- $\alpha$ rhamnopyranoside. These compounds prevent interleukin-2 (IL-2) and interferon- $\gamma$ (IFN- $\gamma$ ) production in peripheral blood mononuclear cells (PBMC). 


\section{Table 3. Continued

Wax apple$$
\text { part }
$$

Leaves extract/fraction

\section{Metabolite content}

Biological Activities

Dichloromethane

Triterpenes and sterol such as -

cycloartenyl stearate (1), lupenyl stearate (2), sitosteryl stearate (3), and 24-methylenecycloartanyl stearate (4).

2',4'-dihydroxy-6'methoxy-3'-

methylchalcone (5), 2',4'-dihydroxy6'methoxy-3',5'-dimethylchalcone (6), 2'hydroxy-4',6'-dimethoxy-3'methyl chalcone (7), squalene (8), botulin (9), lupeol (10), sitosterol (11) and triterpenes and sterol mixtures.

\begin{tabular}{|c|c|c|}
\hline Leaves & Hexane & $\begin{array}{l}\text { - 2'-hydroxy-4',6'-dimethoxy-3'- } \\
\text { methylchalcone (1), 2',4'-dihydroxy-6'- } \\
\text { methoxy-3',5'-dimethylchalcone (2), } \\
\text { 2',4'-dihydroxy-6'-methoxy- } \\
\text { 3'methylchalcone (3) and 7-hydroxy-5- } \\
\text { methoxy-6,8-dimethylchalchone (4). } \\
\alpha \text {-carotene and } \beta \text {-carotene mixture (5), } \\
\text { lupeol (6), botulin (7), epi-betulinic acid } \\
\text { (8), and 7-hydroxy-5-methoxy-6,8- } \\
\text { dimethylflavanone (9), } \beta \text {-sitosterol (10) } \\
\text { and } \beta \text {-D-sitosterylglucoside (11). }\end{array}$ \\
\hline Leaves & Essential oils & $\begin{array}{l}\alpha \text {-pinene }(24,2 \%)(1), \text { limonene }(7,0 \%) \\
\text { (2), } \beta \text {-pinene }(11,7 \%)(3) \text { and } p \text {-cymene } \\
(7,4 \%)(4) .\end{array}$ \\
\hline
\end{tabular}

The compound mixture shows analgesic activity and anti-inflammatory activity at $6,25 \mathrm{mg} / \mathrm{kg}$ body weight and $12,5 \mathrm{mg} / \mathrm{kg}$ body weight, respectively. Furthermore, the compound mixture reveals negligible toxicity toward zebrafish embryonic tissues (Raga et al., 2011).

The triterpenes and sterol mixtures exhibit low to moderate antifungal and antibacterial activity (Ragasa, Franco Jr, Raga, \& Shen, 2014).

\section{Compound 1-4 show relaxant activity; Compound 2} shows spasmolytic activity and neurodegenerative abnormality treatment (Amor, Villaseñor, Nawaz Hussain, \& Choudhary, 2005; Ghayur et al., 2006).

It can be developed as to blockade calcium influx in diarrhea (Ghayur et al., 2006). Aurentiacin (2'-hydroxy-4',6'-dimethoxy-3'- Amor, Villaseñor, methylchalcone) reveals anti-inflammatory activity Ghayur, Gilani, \& by preventing nuclear factor-kB (NF-kB) activation in Choudhary, 2005) mouse macrophages (Kim et al., 2012).

(Kim et al., 2012).

(Farag et al., 2018)

The bark extract of 'Green' cultivar reveals the (M. M. Khandaker, highest antioxidant activity than 'Masam Manis Pink' Sarwar, Mat, \& and 'Jambu Madu Red'.
Boyce, 2015) 
Table 3. Continued

- Wax apple fruit dried powder (DP) contains moisture (16\%), crude fat $(3.85 \%)$, crude protein $(2.32 \%)$, ash $(2.32 \%)$, crude fiber $(5.19 \%)$, available carbohydrate $(75.04 \%)$, total dietary fiber $(8.86 \%)$, total phenolics $(872.69$ mg GAE/100g DP), total flavonoid (148.21 mg QE/100g DP) and total anthocyanin content (11.66 mg CGW/100g DP).

- Wax apple fruit contain moisture (80\%), total phenolic compound $(1.07 \mathrm{mg}$ $\mathrm{GAE} / \mathrm{g}$ FW), ascorbic acid (1.6 $\mu \mathrm{g} \mathrm{AA} / \mathrm{g}$ FW), Lutein $(0.07 \mu \mathrm{g} / \mathrm{g} \quad \mathrm{FW}), \quad \beta-$ cryptoxanthin $(0.02 \mu \mathrm{g} / \mathrm{g} F W)$ and $\alpha$ tocopherol $(0.08 \mu \mathrm{g} / \mathrm{g} F W)$, and $\gamma$ tocopherol $(0.18 \mu \mathrm{g} / \mathrm{g} \mathrm{FW})$.

- Ellagitannin vescalagin / vescalagin

- S. samarangense var. Taiwan pink fruit contains cyanidin 3-glucoside, quercitrin, ellagic acid, and myricetin (Reynertson et al., 2008).

- Wax apple fruit 'Masam Manis Pink' and 'Jambu Madu Red' cultivars contain the highest sources of anthocyanin, carotene, and vitamin $\mathrm{C}$.
Wax apple fruit dried powder reveal antidiabetic Isabelle activity toward streptozotocin (STZ) diabetic rats (2010); through oxidative stress and pro-inflammatory (Shen \& Chang, cytokine inhibition, and anti-apoptotic protein 2013); activation. Wax apple treatment reveals lowered (Shen, Chang, \& fasting blood glucose (FBG) and enhanced body Chang, 2012); weight of diabetic rats. Furthermore, improvement of (Shen, Chang, \& pancreatic $\beta$-cell function is marked by enhanced Chang, 2013);

HOMA-B and insulin level in the pancreas and serum (Zhang, Zhou, et al., of diabetic rats. Pancreatic apoptosis and dysfunction 2016);

of the diabetic rats are prevented by caspace-3 and (Zhang, Wang, et al., Bax protein down-regulated expression and Bcl-2 and 2016);

Bcl-xl protein upregulated expression. In addition, (Reynertson et al., oxidative stress and pro-inflammatory cytokine 2008);

inhibition are developed by inducing CAT and SOD (Khamchan et al., activities, and diminishing nitrotyrosine and TNF- $\alpha$ 2018)

level (Khamchan, Paseephol, \& Hanchang, 2018). $\quad$ (M. M. Khandaker et

Vescalagin of wax apple fruit can be developed as al., 2015).

therapeutic value as anti-hypertriglyceridemic and anti-hyperglycemic effects. Vescalagin at $30 \mathrm{mg} / \mathrm{kg}$ administrated to high-fructose diet (HFD)-induced diabetic rats can decrease fasting blood glucose, Cpeptide, fructosamine, triglyceride, and fatty acid content. Meanwhile, high-density lipoprotein content enhances as $14.4 \%$ in the HFD rats (Shen \& Chang, 2013).

- Wax apple fruit contained ellagitannin vescalagin (VES) is potential as antiglycation and antiinflammation in Methylglyoxal (MG)-induced carbohydrate metabolic disorder rats. VES induces insulin secretion of $\beta$-cells in the MG-rats and downregulates pro-inflammation factors implicated in $\mathrm{MG}$ metabolism. Therefore, VES of wax apple fruit can be used as supplements to prevent diabetes mellitus and its complications (W.-C. Chang, Shen, \& Wu, 2013). 


\section{Table 3. Continued}

\section{Wax apple}

The type of extract/fraction
Metabolite content
Biological Activities

- $\quad$ A fraction from wax apple fruit (FWFE) may decrease insulin resistance by preventing intracellular c-Jun $\mathrm{N}$ terminal kinase (JNK) inflammatory signaling cascades, ameliorating the Phosphatidylinositol-3kinase-protein B (PI3K-Akt/PKB) insulin signaling pathway, and the enhancing glucose uptake in tumor necrosis factor-alpha TNF- $\alpha$-treated FL83B mouse hepatocytes. Therefore, FWFE may develop as antidiabetic drugs, health food, and dietary supplements (Shen et al., 2012).

- Wax apple fruit extract (WAE) can enhance glycolysis, gluconeogenesis, and glycogen storage in the insulinresistant FL83B mouse hepatocytes (Shen et al., 2013).

- Wax apple fruit can protect the liver from alcohol injury. Therefore, wax apple fruit can be recommended as functional food or drug to treat alcohol disorder (Zhang, Wang, et al., 2016; Zhang, Zhou, et al., 2016).

- 'Jambu Madu Red' cultivar shows the best antimicrobial activity than other cultivars (M. M. Khandaker et al., 2015).

- Fruit extract of 'Green' cultivar reveals the highest antioxidant activity than other cultivars (M. M Khandaker et al., 2015). 
Table 3. Continued

\begin{tabular}{|c|c|c|c|c|}
\hline $\begin{array}{l}\text { Wax } \\
\text { apple } \\
\text { part }\end{array}$ & $\begin{array}{l}\text { The type of } \\
\text { extract/fraction }\end{array}$ & $\begin{array}{l}\text { Metabolite } \\
\text { content }\end{array}$ & Biological Activities & References \\
\hline $\begin{array}{l}\text { Fruit } \\
\text { pulp }\end{array}$ & Methanol & $\begin{array}{ll}\text { Reynoutrin } & \mathbf{( 1 )}, \\
\text { hyperin (2), myricitrin } \\
\text { (3), quercitrin (4), }(S)- \\
\text { pinocembrin } \\
\text { quercetin } \\
\text { guaijaverin (7). }\end{array}$ & \multirow{2}{*}{ 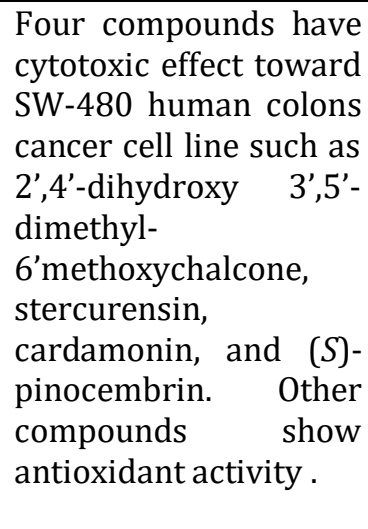 } & \multirow{2}{*}{$\begin{array}{l}\text { (Simirgiotis } \\
\text { et al., 2008) }\end{array}$} \\
\hline Seed & Methanol & $\begin{array}{l}\text { 2',4'-dihydroxy 3',5'- } \\
\text { dimethyl- } \\
\text { 6'methoxychalcone (1), } \\
\text { stercurensin (2), } \\
\text { cardamonin (3), gallic } \\
\text { acid (4) and ellagic acid } \\
\text { (5). }\end{array}$ & & \\
\hline
\end{tabular}

\section{Environmental Stress and Adaptation}

In the flooding condition, wax apple trees appear physiological tolerance mechanisms such as aerenchyma adaptation, induce alcohol dehydrogenase (ADH) enzyme activity, and lowered the respiration rate and vegetative growth. The aerenchyma supply oxygen in the root, inducing ATP production, and adequate to convert 1-aminocyclopropane-1carboxilic acid (ACC) to ethylene. The wax apple will sustain 40 days in flooding conditions (Lin \& Lin, 1992). Furthermore, pest and disease are big challenges influencing phytochemical and physiological characteristics of wax apple. According to the research, Lasiodiplodia theobromae, Pestalotiopsis samarangensis, Fusarium solani, Oligonychus litchi Lo\&Ho, and Anselmella malacia is commonly found in the wax apple plantation.

Lasiodiplodia theobromae, a group of fungi, inflicting black spot disease on wax apple fruit can be controlled by Brevibacillus brevis FJAT0809-GLX strain in the in vitro experiment (Che, Liu, Ruan, Tang, \& Huang, 2015). Pestalotiopsis samarangensis, a new fungal species, has caused fruit rot on wax apple fruit in Thailand. Several symptoms appear on the surface of the wax apple fruit, such as circular, black, and slightly concave spots. Its fungi induce soft decaying of fruit flesh throughout storage. Black conidia induce concentric band on the surface of the wound and surrounding by white mycelium. The spot symptoms can merge become irregular form lesions found into the pulp. Therefore, careful postharvest handling and storage should be applied to prevent the spreading of the disease (Maharachchikumbura, Guo, Chukeatirote, McKenzie, \& Hyde, 2013). Fusarium solani causes twig blight disease in a healthy wax apple fruit tree (Wang, Chen, Lin, Tsou, \& Ko, 2010). In addition, Oligonychus litchi Lo\&Ho, one of major litchi spider mite, founded on wax apple fruit has developmental stages and hatching eggs influenced by temperature. According to Chen et al. (2016), 95\% litchi spider eggs hatch at 20, 25, and $30^{\circ} \mathrm{C}$. For while, the whole developmental stages of litchi spider mite at high temperatures $\left(32^{\circ} \mathrm{C}\right)$ are faster than lower temperatures $\left(16^{\circ} \mathrm{C}\right)$ (W. H. Chen, Li, \& Chang, 2016). Anselmella malacia, a new pest wasp is found in wax apple fruit. Anselmella larvae evolve as seed-eater and reduce fruit quality(Xiao, Xu, Huang, \& Zhao, 2006).

\section{Physiological and Phytochemical Fruit Enhancement}

Physiological and phytochemical fruit characteristics

Eight developmental stages of wax apple fruit classified into young fruits (appropriate to 3 Day After Full Bloom (DAFB) and 13 DAFB, successively), small bell (23 DAFB), big bell (28 DAFB), breaker (34 DAFB), small red (38 DAFB), big red (45 DAFB), and mature (59 DAFB). During wax apple fruit development, water content enhances to $92 \%$ in the breaker stage (34 DAFB) and declines to $88 \%$ in the harvest period (59 DAFB). It is concomitant to the increasing of wax apple fruit dry weight. The size diameter of wax apple fruit increase throughout eight developmental stages. Wax apple fruit diameter size and length increase throughout eight developmental stages. Furthermore, biochemistry characteristics such as total soluble solid content (TSSC), titratable acidity (TA), and anthocyanin reveal a specific pattern based on the developmental stages. At the beginning of the wax apple fruit breaker stage, TSSC shows low concentration and significantly enhances 
corresponding to the declining of TA and water content. Anthocyanin as a color pigment in the wax apple fruit skin appears at the onset of the breaker stages (34 DAFB), especially around the proximal end, it is gradually advanced to the distal end. Calcium concentration enhances until the breaker stages and declines in the further developmental stages. The proximal end of wax apple fruit contains higher calcium concentration than the distal end. It is influenced by the damaging of xylem function. Therefore, the breaker stage is an important developmental stages marked by the onset of skin fruit coloration. Also, reducing the potential risk of corky calyx end disorder (calcium deficiency problem) can be solved by calcium spray application to the young developing of wax apple fruit (S.-J. Chen, Yeh, Lin, \& Li, 2019). Furthermore, soluble solids (SSs) and anthocyanins concentration influenced by sucrose in the cultured medium. Wax apple fruit aged four to eight weeks after anthesis has higher anthocyanin concentration induced by sucrose (Y. J. Chang, Chung, Tseng, Chu, \& Shü, 2003).

The amount of light determines the quality and quantity of wax apple fruit. Different canopy positions will receive different portions of the light. Chlorophyll and stomatal conductance of outer canopy leaves show the highest value than other positions. Outer canopy position of wax apple fruit var. Jambu Madu induce the better quality and quantity of wax apple fruit such as fruit number, fruit size, fruit weight, chlorophyll content, total soluble solid content, and peel color percentage (Mohammad Moneruzzaman Khandaker, Amran, \& Ismail, 2017).

Temperature also influences wax apple fruit quality, such as anthocyanin content, total soluble solids (TSS), soluble sugar (SS), starch, total phenolic compound (TPC), the free amino acid (FA) and soluble protein (SP). During in vitro research, temperature between $20^{\circ}$ and $25^{\circ} \mathrm{C}$ and day/night temperature between $25 / 20^{\circ} \mathrm{C}$ and $25 / 15^{\circ} \mathrm{C}$ shows the best condition inducing the best quality of wax apple fruit (Pan \& Shü, 2007).

\section{Girdling technique}

Enhancing the quality of wax apple fruit quality in the field condition is achieved by the girdling technique. Its technique take place by strip bark removal from the trunk or major branch of fruit tree, thereby photo-assimilate translocation is blocked. Application of girdling technique before flowering increases inflorescence development, yield, and quality of wax apple fruit in the field condition. The Cshaped girdling enhances the inflorescence progress, chlorophyll fluorescence, fruit storage, the number of wax apple fruit, fit weight, dry matter, chlorophyll content, total sugar, total phenol, and anthocyanin content. Meanwhile, the V-shaped girdling influence total flavonoid and antioxidant activity of wax apple fruits. The $\mathrm{C}$ and V-shaped girdling is the promising girdling techniques to improve fruit retention, yield, and quality of wax apple fruit in the field condition (Mohammad Moneruzzaman Khandaker, Hossain, Osman, \& Boyce, 2011). These findings are supported by (Mohammad Moneruzzaman Khandaker, Osman, Hossain, \& Boyce, 2012) showed that the $\mathrm{C}$-shaped girdling technique shows enhancing fruit growth production, and inducing the best final fruit length and diameter. Furthermore, it increases yield, juice percentage, dry leaf matter, biomass, and TSS content. Therefore, C-shape girdling application two weeks before flowering is the best-girdling treatment to improve fruit growth, yield, and quality of wax apple fruit in the field condition (Mohammad Moneruzzaman Khandaker, Osman, et al., 2012).

\section{Hydrogen peroxide treatment}

Hydrogen peroxide treatment reduces the loss of exhaustive chilling-induced wax apple fruit abscission (Lai, Mao, Yo, Hsu, \& Lin, 2001). Hydrogen peroxide spraying treatment result in enhancing fruit growth, yield, and quality of wax apple fruit in the field condition. The optimum $\mathrm{H}_{2} \mathrm{O}_{2}$ spraying treatment concentrations are 5 and $20 \mathrm{mM}$. Once a week, this $\mathrm{H}_{2} \mathrm{O}_{2}$ treatment is sprayed in the leaves, flower, and small fruit of the selected uniform branches throughout the wax apple var. Jambu Madu fruit development (Mohammad Moneruzzaman Khandaker, Boyce, \& Osman, 2012). Furthermore, combination $\mathrm{H}_{2} \mathrm{O}_{2}$ treatment and methyl eugenol or methyl eugenol treatment play an important role in reducing fruit fly infestation in wax apple fruit under field conditions (Mohammad Moneruzzaman Khandaker, Ismail, Hafiza, Mat, \& Ngah, 2018). Moreover, utilizing $\mathrm{H}_{2} \mathrm{O}_{2}$ treatment should consider environmental safety and health care procedures (Lai et al., 2001).

\section{Plant growth regulators treatment}

Plant growth regulators $\left(\mathrm{GA}_{3}, \mathrm{NAA}, 2,4-\mathrm{D}\right)$ treatment on the wax apple var. Jambu Madu fruit tree will enhance physiological and phytochemical fruit characteristics. Once a week, PGRs are applied on the leaves, flower, and small fruit of the selected uniform branches from bud development until fruit ripening. Gibberellic acid $\left(\mathrm{GA}_{3}\right)$, Naphthalene acetic acid (NAA), and 2,4dichlorophenoxyaceticacid (2,4-D) treatment reveal diminishing titratable acidity and increasing total sugar and carbohydrate content. Furthermore, the influence of $50 \mathrm{mg} / \mathrm{L} \mathrm{GA}_{3}, 10$ 
$\mathrm{mg} / \mathrm{L} \mathrm{NAA}$, and $5 \mathrm{mg} / \mathrm{L}$ 2,4-D treatment are increasing phenol, flavonoid and vitamin $\mathrm{C}$ content, affecting chlorophyll, anthocyanin and carotene content, and enhancing antioxidant activity level. Moreover, sensory assessments of fruit treated with $\mathrm{GA}_{3}$ or auxin reveal the highest score than other treatments (Moneruzzaman Khandaker, Nasrulhaq Boyce, Osman, \& Sharif Hossain, 2012)(Moneruzzaman, Hossain, Normaniza, \& Boyce, 2011).

\section{Fruit bagging treatment}

Fruit bagging treatment prevents fruit flies, birds, and rats attack. Although white plastic is suitable to produce the better quality and quantity of wax apple 'Thabthimchan' cultivar, it cannot prevent wax apple fruit from birds. Therefore, red and yellow plastic bags recommended as a white plastic replacement because those color bags will produce similar quality and quantity of wax apple fruit Thabthimchan' cultivar covered by the white plastic bag. The mean weight of 'Thabthimchan' fruit is 142,62 g (red bag) and 140,70 (yellow bag). Meanwhile, the total soluble content of 'Thabthimchan' fruit is $9,73^{\circ}$ Brix (red bag) and 9,55 Brix (yellow bag) (Mothina \& Yapwattanaphun, 2017). On the wax apple 'Thongsamsee' fruit, fruit bagging is applied at the stamen abscission stage. It will reduce fruit flies and fruit drop(Muchjajib et al., 2016)

$S$. samarangense 'Thongsamsee' fruit can be influenced by either GA and NAA application or fruit wrapping. GA treatment at $2500 \mathrm{mg} \mathrm{L}^{-1}$ enhance fruit size, fruit yield, and fruit quality. The fruit color will enhance throughout the GA application at $2500-5000 \mathrm{mg} \mathrm{L}^{-1}$. Meanwhile, NAA treatment at $5000 \mathrm{mg} \mathrm{L}^{-1}$ enhances fruit size, yield, and fruit quality but the fruit shape is dissimilar with the origin cultivar. The better PGRs application time is at the stamen abscission stage and immediately bagged with a plastic bag, vented, and lined with newspaper for air circulation(Muchjajib et al., 2016).

\section{Post-harvest Technology}

\section{Nitric oxide treatment}

Cottony softening appeared in wax apple fruit can be prevented using nitric oxide treatment by several mechanisms such as arrangements of cell wall degradation, oxidation-reduction, carbohydrate metabolism, and signal transduction pathway of plant hormone. Therefore, NO potentially is utilized in the postharvest technology of wax apple fruit (F. Chen, Hao, Yin, Wu, \& Jiang, 2017). According to Hao et al., 2016, nitric oxide (NO) is an appropriate postharvest treatment to delay the wax apple fruit softening and senescence. During storage, NO treatment maintains fruit assertiveness, reducing weight loss, and delay cottony softening. NO treatment $(10 \mu \mathrm{L} / \mathrm{L})$ can regulate the expression of the related genes and enzyme activity in the lignin biosynthesis (Hao, Chen, Wu, \& Gao, 2016).

\section{Storage treatment and challenges}

Oxalic acid treatment is the best treatment to maintain fresh-cut wax apple fruit quality because it can preserve antioxidant activity, total phenolic content, and storage of fruit assertiveness (Izzah, Awang, Ding, Hafiza, \& Satar, 2015). Decreasing whiteness index and enhancing the browning index of fresh-cut wax apple flesh is useful in fruit quality determination of fresh-cut wax apple fruit. Cold treatment at $4 \pm$ $2{ }^{\circ} \mathrm{C}$ prevents the flesh color changing and maintains the peel color and nutritional value of fresh-cut wax apple fruit throughout storage (Supapvanich, Pimsaga, \& Srisujan, 2011). Furthermore, Aloe vera gel coating can preserve and delay the browning process of fresh-cut wax apple fruit cv. Taaptimjaan during storage (Supapvanich et al., 2016). Salicylic acid preharvest treatment at $0.5 \mathrm{mM}$ concentration can maintain the physiochemical quality of wax apple fruit throughout short-term storage. Antioxidant, total phenols and total flavonoid contents increase during salicylic acid pre-harvest treatment (Supapvanich, Mitsang, \& Youryon, 2017). During wax apple fruit storage at room temperature $\left(23^{\circ} \mathrm{C} \pm 1^{\circ} \mathrm{C}\right)$ with $88 \%$ relative humidity, it might be appeared spoilage microorganisms either bacteria or fungi. According to Esua et al., 2017, Klebsiella pneumoniae and Penicillium purpurogenum are the most common spoilage microorganisms in the wax apple fruit throughout storage. Those microorganisms have various effect on phenolic compounds and vitamin $\mathrm{C}$ of wax apple fruit. Therefore, it is essential to prevent contamination in the post-harvest technology (Esua, Chin, Yusof, \& Sukor, 2017).

\section{Wax Apple Product Development}

An ointment containing wax apple fruit ethanolic extract enhances wound healing process of the skin burn in Rattus Wistar. Flavonoid and Saponin may play an important role to increase macrophage activation to produce growth factors and cytokine. Therefore, it will produce collagen and wound quickly closed (Insani et al., 2017). Furthermore, the ethanolic extract of wax apple fruit has been developed as anti-acne cream. According to the research, antiacne cream containing wax apple fruit extract exhibits antibacterial activity toward 
Staphylococcus aureus, Salmonella enterica, and Escherichia coli using the disc diffusion method. In addition, anti-acne cream should be tested in other bacteria causing skin acne (Sekar \& Halim, 2017). Meanwhile, in Indonesia, wax apple fruit becomes the substrate in nata food production. Nata-de guava exhibits the good rendemen, thicknesses, water content, color, taste, and texture when added by $5 \%$ sprout extract (Phaseolus vulgaris) and 5\% sucrose. Sprout extract and sucrose may play an important role as a nitrogen source and carbon source for Acetobacter xylinum growth (Setiani, Pramono, \& Darmawan, 2019).

\section{Future Perspectives}

The development of molecular biology, chemistry, and post-harvest technology can support research expansion of wax apple fruit. Wax apple fruit cultivars can be identified with DNA barcoding or DNA fingerprinting. It will facilitate plant breeding and agricultural sectors. Furthermore, the metabolomics approach can be used to determine the excellent characteristics of each wax apple cultivars. Physiological and phytochemical treatment can be spread to the farmer in the wax apple tree plantation so that it will enhance the yield and fruit production. Therefore, every challenge is expected to solve based on the research implementation.

\section{Conclusion}

Wax apple (Syzygium samarangense (Blume) Merr. \& L.M. Perry) has high diversity in cultivars and can cultivate in the tropical region. It contains various metabolites that have biological activities such as antioxidant activity, immunomodulatory activity, antibacterial activity, anticancer activity, anti-glycation and anti-inflammation activity, antihypertriglyceridemic, anti-hyperglycemic, relaxant activity, spasmolytic activity and neurodegenerative abnormality treatment, analgesic, and central nervous system (CNS) depression agent. Furthermore, the enhancement of wax apple physiological and phytochemical characteristics can be developed by girdling technique, hydrogen peroxide treatment, plant growth regulators treatment, and fruit bagging treatment. Meanwhile, postharvest technology of wax apple fruit uses nitric oxide treatment, oxalic acid treatment, cold treatment, and Aloe vera gel coating. Wax apple has been developed as an ointment, anti-acne cream, and nata de guava. However, environmental stress will be a challenge in the wax apple plantation. Therefore, the development of molecular biology, chemistry, and post-harvest technology will solve those challenges.

\section{References}

Amor, Evangeline C, Villasenor, I. M., Yasin, A., \& Choudhary, M. I. (2004). Prolyl Endopeptidase Inhibitors from Syzygium samarangense (Blume) Merr. \& L. M. Perry. Zeitschrift Fur Naturforschung.C Journal of Biosciences, 59(1-2), 86-92.

Amor, E. C., Villaseñor, I. M., Ghayur, M. N., Gilani, A. H., \& Choudhary, M. I. (2005). Spasmolytic Flavonoids from Syzygium samarangense (Blume) Merr. \& L.M. Perry. Zeitschrift Fur Naturforschung - Section $C$ Journal of Biosciences, 60(1-2), 67-71. https://doi.org/10.1515/znc-2005-1-213

Amor, E. C., Villaseñor, I. M., Nawaz, S. A., Hussain, M. S., \& Choudhary, M. I. (2005). A dihydrochalcone from Syzygium samarangense with anticholinesterase activity. Philippine Journal of Science, 134(2), 105-111.

Chang, W.-C., Shen, S.-C., \& Wu, J. S.-B. (2013). Protective effects of vescalagin from Pink wax apple [Syzygium samarangense (Blume) Merrill and Perry] fruit against methylglyoxal-induced inflammation and carbohydrate metabolic disorder in rats. Journal of Agricultural and Food Chemistry, 61(29), 7102-7109. https://doi.org/10.1021/jf4020284

Chang, Y. J., Chung, M. Y., Tseng, M. N., Chu, C. C., \& Shü, Z. H. (2003). Developmental stages affect characteristics of wax apple fruit skin discs cultured with sucrose - with special reference to color. Scientia Horticulturae, 98(4), 397-407. https://doi.org/10.1016/S03044238(03)00041-4

Che, J., Liu, B., Ruan, C., Tang, J., \& Huang, D. (2015). Biocontrol of Lasiodiplodia theobromae, which causes black spot disease of harvested wax apple fruit, using a strain of Brevibacillus brevis FJAT-0809GLX. Crop Protection, 67, 178-183. https://doi.org/10.1016/j.cropro.2014.10. 012

Chen, F., Hao, Y., Yin, Z., Wu, G., \& Jiang, X. (2017). Transcriptome of wax apple (Syzygium samarangense) provides insights into nitric oxide-induced delays of postharvest cottony softening. Acta Physiologiae 


Plantarum, $\quad 39(12), \quad 1-12$.
https://doi.org/10.1007/s11738-017-
2569-4

Chen, S.-J., Yeh, D.-M., Lin, H.-L., \& Li, K.-T. (2019). Discontinuity of xylem function during maturation associated with quality development and calcium allocation in wax apple (Syzygium samarangense Merr. \& Perry) fruit. Fruits, 74(3), 117-123. https://doi.org/10.17660/th2019/74.3.3

Chen, W. H., Li, C. Y., \& Chang, T. Y. (2016). Temperature-dependent development and life history of Oligonychus litchii (Acari: Tetranychidae), on wax apple. Journal of Asia-Pacific Entomology, 19(1), 173-179. https://doi.org/10.1016/j.aspen.2016.01.0 04

Cheong, M. L. S., \& Ranghoo-Sanmukhiya, V. M. (2013). Phylogeny of syzygium species using morphological, RAPD and ISSR markers. International Journal of Agriculture \& Biology, 15(3), 511-516.

Choironi, N. A., \& Fareza, M. S. (2018). Phytochemical Screening and Antibacterial Activity of Ethanolic Extract of Syzygium samarangense Leaves. Jurnal Kartika Kimia, 1(1), https://doi.org/10.26874/jkk.v1i1.2

Esua, J. O., Chin, N. L., Yusof, Y. A., \& Sukor, R. (2017). Antioxidant Bioactive Compounds and Spoilage Microorganisms of Wax Apple (Syzygium samarangense) during Room Temperature Storage. International Journal of Fruit Science, 17(2), 188-201. https://doi.org/10.1080/15538362.2017. 1285263

Farag, N. F., El-Ahmady, S. H., Abdelrahman, E. H., Naumann, A., Schulz, H., Azzam, S. M., \& ElKashoury, E. S. A. (2018). Characterization of essential oils from Myrtaceae species using ATR-IR vibrational spectroscopy coupled to chemometrics. Industrial Crops and Products, 124, 870-877. https://doi.org/10.1016/j.indcrop.2018.0 7.066

Ghayur, M. N., Gilani, A. H., Khan, A., Amor, E. C., Villaseñor, I. M., \& Choudhary, M. I. (2006). Presence of calcium antagonist activity explains the use of Syzygium samarangense in diarrhoea. Phytotherapy Research, 20(1), 49-52. https://doi.org/10.1002/ptr.1801

Hao, Y., Chen, F., Wu, G., \& Gao, W. (2016). Impact of postharvest nitric oxide treatment on lignin biosynthesis-related genes in wax apple (Syzygium samarangense) fruit. Journal of Agricultural and Food Chemistry, 64(45), 8483-8490. https://doi.org/10.1021/acs.jafc.6b03281

Idris, N. S., Ismail, S. Z., Mat, N., \& Khandaker, M. M. (2018). Comparative physiological response of three wax apple (Syzygium samarangense) tree cultivars at flower bud development stage. Bioscience Research, 15(1), 402-411.

Insani, A. Y., Prameswari, M. C., Muharrom, N. A., Hidayati, T., Nugrahani, A. P., \& Sakinah, E. N. (2017). Syzygium Samarangense Leaves Ointment Enhances Wound Healing Process Of Skin Burn Based On Collagen. Journal of Agromedicine and Medical Sciences, 3(3), 30-33.

https://doi.org/10.19184/ams.v3i3.6160

Izzah, N. K., Awang, Y., Ding, P., Hafiza, Y., \& Satar, M. G. M. (2015). Antioxidant, polygalacturonase, pectin methylesterase and polyphenol oxidase activities of freshcut wax apple (Syzygium samarangense) treated with organic acids. Asian Journal of Plant Sciences, 14(2), 72-77. https://doi.org/10.3923/ajps.2015.72.77

Kamada, Y., Yakabu, H., Ichiba, T., Tamanaha, A., Shimoji, M., Kato, M., ... Tanaka, Y. (2018). Castalagin and vescalagin purified from leaves of Syzygium samarangense (Blume) Merrill \& L.M. Perry: dual inhibitory activity against PARP1 and DNA topoisomerase II. Fitoterapia, 129, 94-101. https://doi.org/10.1016/j.fitote.2018.06.0 15

Khamchan, A., Paseephol, T., \& Hanchang, W. (2018). Protective effect of wax apple (Syzygium samarangense (Blume) Merr. \& L.M. Perry) against streptozotocin-induced pancreatic ß-cell damage in diabetic rats. Biomedicine and Pharmacotherapy, 108, 634-645.

https://doi.org/10.1016/j.biopha.2018.09. 072

Khandaker, M. M., Sarwar, J. M., Mat, N., \& Boyce, A. N. (2015). Bioactive constituents, antioxidant and antimicrobial activities of three cultivars of wax apple (Syzygium samarangense L.) fruits. Research Journal of Biotechnology, 10(1), 7-16.

Khandaker, Mohammad Moneruzzaman, Alebidi, A. I., \& Al-saif, A. M. (2012). Assesment of genetic diversity in three cultivars of Syzygium samarangense grown in Malaysia 
by using morphological and physiological parameters. Research Journal of Biotechnology, 7(3), 16-22.

Khandaker, Mohammad Moneruzzaman, Alebidi, A. I., Hossain, A. S., Mat, N., \& Boyce, A. N. (2015). Physiological and biochemical properties of three cultivars of wax apple (Syzygium samarangense [Blume] Merrill \& L.M. Perry) fruits. Journal of Sustainability Science and Management, 10(1), 66-75.

Khandaker, Mohammad Moneruzzaman, Amran, N. Q., \& Ismail, S. Z. (2017). Effect of canopy position on growth, quality and quantity of Syzygium samarangense (wax apple var. jambu madu) fruits. Australian Journal of Crop Science, 11(7), 838-843. https://doi.org/10.21475/ajcs.17.11.07.pn e485

Khandaker, Mohammad Moneruzzaman, Boyce, A. N., \& Osman, N. (2012). The influence of hydrogen peroxide on the growth, development and quality of wax apple (Syzygium samarangense, [Blume] Merrill \& L.M. Perry var. jambu madu) fruits. Plant Physiology and Biochemistry, 53, 101-110. https://doi.org/10.1016/j.plaphy.2012.01. 016

Khandaker, Mohammad Moneruzzaman, Hossain, A. S., Osman, N., \& Boyce, A. N. (2011). Application of girdling for improved fruit retention, yield and fruit quality in Syzygium samarangense under field conditions. International Journal of Agriculture and Biology, 13(1), 18-24.

Khandaker, Mohammad Moneruzzaman, Ismail, S. Z., Hafiza, N., Mat, N., \& Ngah, N. (2018). Effects of hydrogen peroxide and methyl eugenol on fruit growth, yield and fruit fly infestation of Syzygium samarangense. International Journal of Engineering \& Technology, 7(4.43), 54-58.

Khandaker, Mohammad Moneruzzaman, Osman, N., Hossain, A. S., \& Boyce, A. N. (2012). Effects of the phloemic stress on the growth, development and quality of wax apple (Syzygium samarangense) cv. Jambu madu. Sains Malaysiana, 41(5), 553-560.

Kim, Y. J., Kim, H. C., Ko, H., Amor, E. C., Lee, J. W., \& Yang, H. O. (2012). Inhibitory effects of aurentiacin from Syzygium samarangense on lipopolysaccharide-induced inflammatory response in mouse macrophages. Food and Chemical Toxicology, 50(3-4), 1027-1035. https://doi.org/10.1016/j.fct.2011.11.050

Kuo, Y.-C., Yang, L.-M., \& Lin, L.-C. (2004) Isolation and immunomodulatory effect of flavonoids from Syzygium samarangense. Planta Medica, 70(12), 1237-1239. https://doi.org/10.1055/s-2004-835859

Lai, J. M., Tsai, C. C., Yen, C. R., Ko, Y. Z., Chen, S. R., Weng, I. S., ... Chiang, Y. C. (2015). Molecular characterization of twenty polymorphic microsatellite markers in the polyploid fruit tree species Syzygium samarangense (Myrtaceae). Genetics and Molecular Research, 14(4), 13013-13021. https://doi.org/10.4238/2015.0ctober.21. 22

Lai, Mao, R., Yo, S.-P., Hsu, Y.-M., \& Lin, C.-H. (2001). Hydrogen peroxide application reduced fruit abscission on chillingstressed Syzygium samarangense Merr. et Perry. Gartenbauwissenschaft, 66(6), 289292.

Lin, C. H., \& Lin, C. H. (1992). Physiological adaptation of waxapple to waterlogging. Plant, Cell \& Environment, 15(3), 321-328. https://doi.org/10.1111/j.13653040.1992.tb00980.x

Liu, J., Ni, S.-B., Zheng, C., Shi, C., \& Niu, Y.-F. (2018). Chloroplast genome of tropical and sub-tropical fruit tree Syzygium samarangense (Myrtaceae). Mitochondrial DNA Part B, 3(2), 890-891. https://doi.org/10.1080/23802359.2018. 1501296

Maharachchikumbura, S. S. N., Guo, L.-D., Chukeatirote, E., McKenzie, E. H. C., \& Hyde, K. D. (2013). A destructive new disease of Syzygium samarangense in Thailand caused by the new species Pestalotiopsis samarangensis. Tropical Plant Pathology, $38(3)$, 227-235. https://doi.org/10.1590/S198256762013005000002

Majumder, R., Alam, M. B., Chowdhury, S. T., Bajpai, V. K., \& Shukla, S. (2017). Quantitative measurement of bioactive compounds from leaves of syzygium samarangense with antioxidant efficacy. Journal of the National Science Foundation of Sri Lanka, 45(2), 169-178. https://doi.org/10.4038/jnsfsr.v45i2.8182

Majumder, R., Nur-E-Hasnat, Ashraf-Uz-Zaman, M., \& Alam, M. B. (2014). In vivo evaluation of the pharmacological activities of Syzygium samarangense (Blume) Merr. \& 
L.M. Perry. Advances in Biological Research, 8(3), 107-115. https://doi.org/10.5829/idosi.abr.2014.8. 3.81225

Mamdouh Nabil Samy, Sugimoto, S., Matsunami, K., Otsuka, H., \& Kamel, M. S. (2014). Taxiphyllin 6'-0-Gallate, Actinidioionoside 6'-0-Gallate and Myricetrin 2"-0-Sulfate from the Leaves of Syzygium samarangense and Their Biological Activities. Chemical and Pharmaceutical Bulletin, 62(10), 10131018. https://doi.org/10.1248/cpb.c14e6211

Matra, D. D., Ritonga, A. W., Natawijaya, A., Poerwanto, R., Sobir, Siregar, U. J., ... Inoue, E. (2019). Datasets for genome assembly of six underutilized indonesian fruits. Data in Brief, 22, 960-963. https://doi.org/10.1016/j.dib.2018.12.070

Milow, P., Malek, S. B., Edo, J., \& Ong, H.-C. (2014). Malaysian Species of Plants with Edible Fruits or Seeds and Their Valuation. International Journal of Fruit Science, 14(1), 1-27.

https://doi.org/10.1080/15538362.2013. 801698

Moneruzzaman, K. M., Al-Saif, A. M., Alebidi, A. I., Hossain, A. B. M. S., Normaniza, O., \& Boyce, N. A. (2011). An evaluation of the nutritional quality evaluation of three cultivars of Syzygium samarangense under Malaysian conditions. African Journal of Agricultural Research, 6(3), 545-552. https://doi.org/10.5897/AJAR10.923

Moneruzzaman, K. M., Hossain, A. B. M. S., Normaniza, O., \& Boyce, A. N. (2011). Growth, yield and quality responses to gibberellic acid (GA 3) of wax apple Syzygium samarangense var. Jambu air madu fruits grown under field conditions. African Journal of Biotechnology, 10(56), 11911-11918.

https://doi.org/10.5897/AJB10.1692

Moneruzzaman Khandaker, M., Nasrulhaq Boyce, A., Osman, N., \& Sharif Hossain, A. (2012). Physiochemical and phytochemical properties of wax apple (syzygium samarangense [Blume] Merrill \& L. M. Perry var. Jambu Madu) as affected by growth regulator application. The Scientific World Journal, 2012. https://doi.org/10.1100/2012/728613

Morton, J. F. (1987). Fruit of Warm Climates. https://doi.org/10.1201/b22001-27
Mothina, N., \& Yapwattanaphun, C. (2017). Effect of bagging colour on fruit quality of wax apple (Syzygium samarangense (Blume) Merr. \& Perry) 'Thabthimchan.' Acta Horticulturae, 1166, 191-194. https://doi.org/10.17660/ActaHortic.201 7.1166.27

Muchjajib, S., Muchjajib, U., \& Jumee, M. (2016). Effects of GA and NAA application and fruit wrapping on yield and quality of Java apple (Syzygium samarangense (Blum) Merrill \& Perry). Acta Horticulturae, 1130, 225-230. https://doi.org/10.17660/ActaHortic.201 6.1130 .33

Nair, A. G. R., Krishnan, S., Ravikrishna, C., \& Madhusudanan, K. P. (1999). New and rare flavonol glycosides from leaves of Syzygium samarangense. Fitoterapia, 70(2), 148-151. https://doi.org/10.1016/S0367326X(99)00013-1

Nogueira, A. M., Ferreira, A., \& da Silva Ferreira, M. F. (2016). Transferability of microsatellites from Psidium guajava to Eugenia, Myrciaria, Campomanesia, and Syzygium Species (Myrtaceae). Plant Molecular Biology Reporter, 34(1), 249256. https://doi.org/10.1007/s11105015-0921-7

Pan, H., \& Shü, Z. (2007). Temperature affects color and quality characteristics of "Pink" wax apple fruit discs. Scientia Horticulturae, 112(3), 290-296. https://doi.org/10.1016/j.scienta.2006.12. 046

Raga, D. D., Cheng, C. L. C., Lee, K. C. I. C., Olaziman, W. Z. P., Guzman, V. J. A. De, Shen, C.-C., ... Ragasa, C. Y. (2011). Bioactivities of Triterpenes and a Sterol from Syzygium samarangense. Zeitschrift Für Naturforschung C, 66(May), 0235. https://doi.org/10.5560/znc.2011.66c023 5

Ragasa, C. Y., Franco Jr, F. C., Raga, D. D., \& Shen, C.-C. (2014). Chemical constituents of Syzygium samarangense. Der Pharma Chemica, 6(3), 256-260.

Reynertson, K. A., Yang, H., Jiang, B., Basile, M. J., \& Kennelly, E. J. (2008). Quantitative analysis of antiradical phenolic constituents from fourteen edible Myrtaceae fruits. Food Chemistry, 109(4), 883-890. https://doi.org/10.1016/j.foodchem.2008. 01.021 
Sekar, M., \& Halim, F. H. A. (2017). Formulation and evaluation of natural anti-acne cream containing Syzygium samarangense fruits extract. Annual Research and Review in Biology, 17(3), 1-7. https://doi.org/10.9734/ARRB/2017/364 67

Setiani, B. E., Pramono, Y. B., \& Darmawan, B. R. (2019). The characteristics of nata-de guava (Syzygium samarangense) with certain interaction on the proportion of sprout extract (Phaseolus vulgaris) and sucrose. IOP Conference Series: Earth and Environmental Science, 292(1), 1-5. https://doi.org/10.1088/17551315/292/1/012045

Shahreen, S., Banik, J., Hafiz, A., Rahman, S., Zaman, A. T., Shoyeb, M. A., ... Rahmatullah, M. (2012). Assaying anti-hyperglycemic activities of leaves of three edible fruit plants (Averrhoa carambola, ficus hispida and Syzygium samarangense) of Bangladesh. African Journal of Traditional, Complementary and Alternative Medicines, 9(2), $0-4$. https://doi.org/10.4314/ajtcam.v9i2.16

Shen, S.-C., \& Chang, W.-C. (2013). Hypotriglyceridemic and hypoglycemic effects of vescalagin from Pink wax apple [Syzygium samarangense (Blume) Merrill and Perry cv. Pink] in high-fructose dietinduced diabetic rats. Food Chemistry, 136, 858-863.

https://doi.org/10.1016/j.foodchem.2012. 08.037

Shen, S.-C., Chang, W.-C., \& Chang, C.-L. (2012). Fraction from wax apple [Syzygium Samarangense (Blume) Merrill and Perry] fruit extract ameliorates insulin resistance via modulating insulin signaling and inflammation pathway in tumor necrosis factor $\alpha$-treated FL83B mouse hepatocytes. International Journal of Molecular Sciences, 13 , 8562-8577. https://doi.org/10.3390/ijms13078562

Shen, S.-C., Chang, W.-C., \& Chang, C.-L. (2013). An extract from wax apple (Syzygium samarangense (Blume) Merrill and Perry) effects glycogenesis and glycolysis pathways in tumor necrosis factor- $\alpha$ treated FL83B mouse hepatocytes. Nutrients, 5(2), 455-467. https://doi.org/10.3390/nu5020455
Shü, Z. H., Shiesh, C. C., \& Lin, H. L. (2011). Wax apple (Syzygium samarangense (Blume) Merr. and L.M. Perry) and related species. In Postharvest Biology and Technology of Tropical and Subtropical Fruits (Vol. 4, pp. 458-475). https://doi.org/10.1533/9780857092618. 458

Simirgiotis, M. J., Adachi, S., To, S., Yang, H., Reynertson, K. A., Basile, M. J., ... Kennelly, E. J. (2008). Cytotoxic chalcones and antioxidants from the fruits of Syzygium samarangense (Wax Jambu). Food Chemistry, 107(2), 813-819. https://doi.org/10.1016/j.foodchem.2007. 08.086

Sobeh, M., Petruk, G., Osman, S., Raey, M. A. El, Imbimbo, P., Monti, D. M., \& Wink, M. (2019). Isolation of Myricitrin and 3,5-di-OMethyl Gossypetin from Syzygium samarangense and evaluation of their involvement in protecting keratinocytes against oxidative stress via activation of the Nrf-2 pathway. Molecules, 24, 1-14. https://doi.org/10.3390/molecules24091 839

Sobeh, M., Youssef, F. S., Esmat, A., Petruk, G., ElKhatib, A. H., Monti, D. M., ... Wink, M. (2018). High resolution UPLC-MS/MS profiling of polyphenolics in the methanol extract of Syzygium samarangense leaves and its hepatoprotective activity in rats with CCl4-induced hepatic damage. Food and Chemical Toxicology, 113, 145-153. https://doi.org/10.1016/j.fct.2018.01.031

Supapvanich, S., Mitrsang, P., Srinorkham, P., Boonyaritthongchai, P., \& Wongs-Aree, C. (2016). Effects of fresh Aloe vera gel coating on browning alleviation of fresh cut wax apple (Syzygium samarangenese) fruit cv. Taaptimjaan. Journal of Food Science and Technology, 53(6), 2844-2850. https://doi.org/10.1007/s13197-0162262-4

Supapvanich, S., Mitsang, P., \& Youryon, P. (2017). Preharvest salicylic acid application maintains physicochemical quality of 'Taaptimjaan' wax apple fruit (Syzygium samarangenese) during short-term storage. Scientia Horticulturae, 215, 178-183. https://doi.org/10.1016/j.scienta.2016.11. 046

Supapvanich, S., Pimsaga, J., \& Srisujan, P. (2011). Physicochemical changes in fresh-cut wax apple (Syzygium samarangenese [Blume] 
Merrill \& L.M. Perry) during storage. Food Chemistry, 127(3), 912-917. https://doi.org/10.1016/j.foodchem.2011. 01.058

Wang, P.-H., Chen, Y.-S., Lin, M.-J., Tsou, Y.-J., \& Ko, W.-H. (2010). Severe decline of wax apple trees caused by Fusarium solani in northern Taiwan. Botanical Studies, 51(1), 75-80.

Widodo, P. (2015). Jambu Semarang dan Jambu Air. Universitas Jenderal Soedirman.

Xiao, H., Xu, L.-N., Huang, D.-W., \& Zhao, Z.-Y. (2006). Anselmella malacia, a new pest wasp (Hymenoptera: Chalcidoidea: Eulophidae) reared from Syzygium samarangense in Malaysia. Phytoparasitica, 34(3), 261-264. https://doi.org/10.1007/BF02980953

Yang, J., Su, J.-C., Lei, X.-P., Huang, X.-J., Zhang, D.M., Ye, W.-C., \& Wang, Y. (2018). Acylphloroglucinol derivatives from the leaves of Syzygium samarangense and their cytotoxic activities. Fitoterapia, 129, 1-6. https://doi.org/10.1016/j.fitote.2018.06.0 02

Zhang, Y.-J., Wang, F., Zhou, Y., Li, Y., Zhou, T., Zheng, J., ... Li, H. Bin. (2016). Effects of 20 selected fruits on ethanol metabolism: Potential health benefits and harmful impacts. International Journal of Environmental Research and Public Health, 13(4), 1-13. https://doi.org/10.3390/ijerph13040399

Zhang, Y.-J., Zhou, T., Wang, F., Zhou, Y., Li, Y., Zhang, J.-J., ... Li, H.-B. (2016). The effects of Syzygium samarangense, Passiflora edulis and Solanum muricatum on alcoholinduced liver injury. International Journal of Molecular Sciences, 17(10), 1-12. https://doi.org/10.3390/ijms17101616 